\title{
Barriers for Implementing Solar Energy Initiatives in Nigeria: An Empirical Study
}

\begin{abstract}
Purpose

Despite the abundant renewable energy potential in the Nigeria, power sector stakeholders have not paid attention to the prospect of natural resources that can be utilised when it is properly harnessed. Although, a very negligible fraction of the population has invested in solar photovoltaic (PVs) for home solution, the initiative was only made public commercialised under the public private partnership (PPP) and the objectives of the Power Sector Reform Act. 2005. It is, therefore, aimed to investigate the causes and insight of the barriers that are responsible for the slow implementation of the solar energy initiative in Nigeria.
\end{abstract}

\section{Design/methodology/approach}

An empirical study was performed in Nigeria. The study was conducted qualitatively, through semi-structured face-to face interviews of 25 participants. The interviews were recorded, transcribed, interpreted, coded, categorised into themes, and analysed by content analysis.

\section{Findings}

The study reveals technological, financial, political, and social barriers have been the reason for slowing down solar energy development in Nigeria. While the technical barrier is a challenge to the solar energy implementation, socio-cultural issues have also been an obstacle to the implementation process. It is suggested that the stakeholders of the initiatives, to proffer sustainable policies to enable public and private promoters to be able to generate, and distribute electricity through solar PV, to complement the inadequate conventional electricity sources from the grids.

\section{Originality/value}

The paper provides a richer insight into the understanding and awareness of barriers for implementing solar energy strategies in Nigeria.

Keywords: Barriers to implementation, power sector, solar energy initiatives, technological aspects

\section{Introduction}

Electricity is crucial to socio-economic development, especially in Nigeria, which is one of the biggest economies and most populous nation in Africa. The inability to generate and supply a sustainable electricity in the country is a risk that could cripple the Gross Domestic Product 
(GDP) (Aliyu, et al. 2015). Although, Nigeria is located on a sunshine belt within the SubSahara African region, it is driven away by a huge opportunity to deploy a small fraction of its land to generate electricity from solar photovoltaic (PV) (Giwa, et al. 2017). Ozuegwu, et al. (2017) noted that more than $40 \%$ of the country's population are yet to be connected to the national grid. The grid connected areas are plagued by frequent power outages that last several hours and even days in some instances. Literature evident that few urban cities are connected to the grids with limited electricity access for domestic household and industrial power demand (Ohunakin, et al. 2014; Akuru, et al. 2017). Whilst the rural area habitants rely on traditional charcoal fire, kerosene lanterns, waste residue for bioenergy and very tiny fraction of solar energy for water boreholes and lighting (Okeowu, 2018). The Nigerian power demand and supply gap is estimated to be more than 76\% as of the year 2016 (Mohammed, et al. 2017). The stakeholders have paid little or no attention for the opportunity to harness renewable energy resources, especially solar energy to help the power sector to minimise the demand and supply gap (Babakatcha, et al. 2020). Although Ohunakin, et al. (2014) and Abdullahi, et al. (2017a) have reported key barriers for renewable energy in Nigeria, there is no empirical study reported to identify the barriers for solar energy implementation in Nigeria.

Prior to reporting the findings of the empirical study, this paper provides an overview of solar energy in Nigeria. This discussion starts with a comprehensive literature review by identifying solar energy generation targets followed by the major solar energy projects, implementation and uses of solar energy.

\section{Solar energy overview in Nigeria}

Nigeria is located on the Western coast of Africa on the Gulf of Guinea with an area of 923, $768 \mathrm{~km}^{2}$ making it the world $31^{\text {st }}$ largest country in the world. Nigeria is the most populous black nation on earth with a population of approximately 195 million people in 2017 (Aliyu, et 
al. 2015; Emodi and Boo, 2015). Nigeria as a country is divided into regions off the river Niger and Benue with six geopolitical Zones with Zone I, II and III indicating solar radiation potential in Figure 1.

Figure 1: Sun radiation level in Nigeria (Insert here)

It is evident the highest sunshine radiation of 6.966 is in Nguru, Yobe state and the least is 3.78 in Wari, Delta state in the South-South zone of the country. Furthermore, the northern part of the country has a solar radiation of $7 \mathrm{KWh} / \mathrm{m}^{2}$ while the southern part has $4 \mathrm{KW} \mathrm{h/ \textrm {m } ^ { 2 }}$ respectively (Ozoegwu, et al. 2017). Figure 1 also indicates that the northern part of the country has more solar energy radiation than other regions (Oyedepo, 2018; Nwokolo and Ogbulezie, 2018).

Nigeria has solar radiation adequate to generate sustainable electricity for both household and industrial needs (Ugulu and Aigbayboa, 2019). The Electric Power Sector Reform Act (EPSRA) 2005 has attracted investors, nationally and internationally under the Public Private Partnership (PPP) (Ugulu and Aigbayboa, 2019). Germany has committed 2 million Euro to support Nigerian government towards energy access (Ogunmodimu and Okoroigwe, 2018). Also, the United State of America (USA) emulates to invest 2 million Dollars under the new technology development platform and the implementation process is expected to be completed by 2020. Whilst Finish development financier Finnfund has signed a pioneering 5 million Dollars long-term senior debt financing for Starsight Power Utility Limited (SPUL) group for additional 10 million US Dollars of total funding by mid of 2020 (Ogunmodimu and 
Okoroigwe, 2018). The table below represents solar energy progress in Nigeria in terms of the activities, timeline and the quantity to be produced both through PV and thermal.

Table 1: Solar energy generation in Nigeria (Insert here)

According to table 1, the projection for solar energy generation is expected to exceed $600 \mathrm{MW}$ for a short-term between 2006 - 2009, 6136 MW for medium-term between 2010 - 2015 and 48131 MW for long-term by 2030. The proposed target is equivalent to the total electricity generated from all sources in the country between 2015 and 2017. The solar energy generation should have a growth rate of $1782 \mathrm{MW}$ per annum in order to achieve the 2030 targets. Although, the solar energy target shows a significant growth within the span of 15 years, the reciprocal growth of the population is expected to rise from 186,458,723 million in 2015 to 218,263,539 million in 2020 and 299,073,660 million in 2030 (Akinyele, et al. 2015). Therefore, a review was conducted on the solar energy projects and initiatives to use solar energy in Nigeria.

\section{Solar Energy Projects in Nigeria}

The Electric Power Sector Reform Act was enacted in 2005 to unbundle the Power Holding Company of Nigeria, to transform the power sector and to diversify the energy mix using renewable sources. As a result, hundreds of solar-based energy projects have been approved with progress traceable to rural communities where access to electricity is crucial and the projects are expected to generate $15 \%$ of the country's power by 2020 (Aliyu, et al. 2015). Ohunakin, et al. (2014) noted that EPSRA made the private and public sector for National 
Independent Power Project (NIPP) and Integrated Power Producers (IPP) to achieve 'Operation Light Up Rural Nigeria'.

Table 2 indicates the ongoing solar energy projects in Nigeria as approved and monitored by the Ministries, Departments and Agencies (MDAs) spearheaded by the Federal Ministry of Power (FMP). The projects are expected to generate solar energy to support areas with limited access to electricity, especially the rural communities and small-scale businesses (Ohunakin, et al. 2014; NOVA/KSG, 2018).

Table 2: Major Solar projects in Nigeria (Insert here)

\section{Steps to promote the implementation and use of Solar Energy}

Emodi and Boo (2015) noted that the national energy policy (NEP) of 2003 proposed and approved by the Nigerian government to support solar energy and to increase access to areas with limited grid connections the policy focus on solar PVs, wind turbines and mini-grids systems is to be integrated through PPP to increase electricity access (Akinyele, et al. 2015). The policy emphasis is on the power sector diversification to energy options (NERC, 2020). In addition, the Electric Power Sector Reform Act. 2005 also enacted to integrate PPP to generate electricity from all sources in order increase energy access in the country (Fagbanle, et al. 2011). The Act establishes grounds for the need to unbundle the Power Holding Company of Nigeria (PHCN) to private equities in order to increase the opportunities for energy mix (Akinyele, et al. 2019). Other energy establishments include five centres for energy research across the six geopolitical zones. The centres are saddled for research on solar energy, energy 
efficiency and conservation, hydropower development, petroleum research and development (Okeowo, 2018). Moreover, the National Power Training Institute of Nigeria (NAPTIN) was established for the purpose of training and development for power sector personnel on technical and managerial aspect on power (Mohammed, et al. 2017).

Table 3: Key Institutions Responsible for Electricity deployment in Nigeria (Insert here)

Despite many efforts and the benefits that can be accrued from the use of solar energy (see Table 1) the adoption is still very low. The work done by Kar, et al., (2016), Shukla, et al. (2018) and Kumar, et al., (2020) in the context of India for the implementing solar energy initiatives noted that product knowledge, financial support and subsidies, have an influence on customers' purchase intention of solar products. Financial aspects such as: lack of access to capital, credit to consumers and relevant financial instrument for the implementation of solar initiatives were noted as barriers. So far, there is no empirical results reported in the Nigerian context regarding the barriers for implementing solar energy initiative which is the rationale for this study. Therefore, the research question is what are the barriers for implementing solar energy initiatives in Nigeria?

\section{Methodology}

A qualitative research methodology has been adopted to gain a deep understanding of stakeholder perception towards barriers and towards the realisation of solar energy initiatives. Semi-structured interview was suitable for the data collection because it allows the interviewee to express their views freewill (Creswell and Creswell, 2018). The researcher approached many 
stakeholder organisation's across Nigeria, especially in the capital city where all the MDAs are headquartered, about 36 of the solar energy related MDAs were identified and approached. Only 20 out of the $36(55.6 \%)$ volunteered to participate. Within the 20 MDAs, 25 key position's holders were interviewed (See Table 6). The interviewees were asked the question "What are the key barriers for implementing solar energy initiatives in Nigeria?".

The researcher followed ethical consideration, confidentiality and anonymity with freedom to opt out or to participate without researcher's influence (Neuman, 2014). The face-to-face interview was recorded on a digital recorder and mobile phone recorder for a back-up. The interviews were transcribed into a word document for analysis. The transcripts were carefully studied and coded to extract information for categories and corpus of text related to key barriers and analysed using conventional content analysis. The choice for content analysis was to help reduce the data into a simplified result that matches the research question by quantifying words and concept searched (Creswell and Creswell, 2018). The codes have been cross-checked through group discussions between the authors and two fellow researchers. Threats to validity were minimised through triangulation of data collection methods (interviews, observations, internal and external documents) and verification of the initial codes by participants, where they judged the accuracy of data collected, though not its conclusions (Tajeddini and Mueller, 2009). Codes that emerged were for example on technical aspects which included battery life of solar panels and technical expertise. The themes were formed by grouping codes which are explained in the next section.

Table 6: Research Participants (Insert here) 


\section{Barriers for Solar Energy implementation in Nigeria}

Although, they are abundant solar energy resources available in Nigeria, solar energy continued to gain more recognition from both public and private sectors. However, the barriers for implementation of solar energy initiative in Nigeria revealed are technological, financial, political and social perceptions. These barriers are discussed as follows:

1. Technological barriers: In this study all the interviewees noted that inadequate technology and infrastructure necessary to support solar energy is a key barrier hindering the implementation. Three categories emerged as part of the analysis. They are lack of technical capacity, lack of research and development, and standard and quality control.

\section{a. Lack of technical capacity}

All the interviewees reported that there was a lack of skilled personnel to meet a code of standard procedure, to install and maintain solar PV in the country. This was identified by authors Purohit and Purohit, (2017) and Ohunakin, et al. (2014) explained that inadequate experience and lack of technical know-how could lead to risk of the initiative being rejected by potential customers of solar energy. The technology workability for solar energy needs to be understood by both promoters and end-users. One of the interviewees noted that:

"Technical expertise and training are lacking in the society. Promotion and sensitisation of the public are poor and misunderstood. The technology cannot be fully accepted by end users because they are not well informed of the benefits of solar energy".

Solar energy development in Nigeria is faced with a lack of enabling vision and mission for technology, fine-tuning and promoting the initiative (Haas, et al. 2018). Although, the 
country has opportunities for solar radiation potentials, the market is still immature and the turnout for utilisation is low (Abdullahi, et al. 2017a, Adesanya, et al., 2020). The Power Sector Reform Act. 2005 is a forward step to the Nigerian power sector uprising from conventional electricity to energy mix. However, there is a need to speed the energy strategies to be able to achieve the EPSRA (2005) objectives and increase access to energy mix. Hence, 68\% (17 of the 25) interviewees perceived that substandard and cheaper version of solar energy product results in poor acceptance of the solar energy technology. One of the interviewees said:

"The market for solar energy product and equipment; such as solar panels, power inverters, exclusively battery power and AC generators are yet to be accepted in many parts of Nigeria. As a result, many micro companies floated the market with substandard and cheaper version of the product, resulting in the technology rejection in many areas across the country'.

\section{b. Lack of research and development}

Nigerian solar energy development and promotion is challenged by lack of adequate research and development. The Energy Commission of Nigeria in collaboration with five tertiary institutions has established research centres for solar, renewables, hydropower, petroleum efficiency and conservation resources in Enugu, Sokoto, Lagos, Ilorin, and Bauchi respectively. In addition, a Power Training Institute of Nigeria (NAPTIN) was established for technical and non-technical training courses related to power (NERC, 2020). $52 \%$ (13 of the 25$)$ interviewees noted the following assertion: 
"Northern part of Nigeria is full of potential for solar energy, but the region lacks full capacity for research and development about solar energy technologies in the country".

Weather and climate condition can negatively affect the efficiency and effectiveness of solar panels and batteries which could lead to low output of the initiative. According to Aliyu, et al. (2015) northern part of Nigeria is extremely hot, especially North East and North West. The potential for solar energy panels and storage cannot be efficiently and effectively achieved due to the adverse effect temperature of the weather in the region (Ramli, 2016). The solar panel efficiency is negatively affected by temperature more than $25^{\circ} \mathrm{c}$, as such the effectiveness of the panels can be reduced by $10 \%-25 \%$ whilst the battery storage needs cooling mechanism to enable its functionality (Jacobson and Jadhav, 2018). Therefore, the initiatives tend to suffer weather impact on the northern part of the country where temperature is estimated between $30^{\circ}-45^{\circ} \mathrm{c}$ in Maiduguri, Yobe, Sokoto, Zamfara Niger and Kebbi state. Thus 44\% (11 of the 25) interviewees said about the weather conditions and the lack of research and development in that respect. One of them noted that:

"Most of the solar streetlights in Abuja, Lagos and many other cities in Nigeria died off less than six months of installation, because the batteries were exposed to very hot weather condition'”.

\section{c. Standard and Quality Control}

Lack of standard and quality control are constraint in the development and promotion of solar energy initiatives in Nigeria. This affects potential users, retailers, and promoters for 
solar energy initiatives (Shukla, et al. 2018; Kumar, et al., 2020). It is evident that the Nigeria solar market is floated with substandard solar panels, batteries and accessories, resulting in lack of trust and guarantee to the promoters. Inadequate standard and quality control for the solar energy product is a constraint that can lead to low access to the market penetration, especially the rural areas across the six geopolitical zones. $40 \%$ (10 of the 25 interviewees) respondent noted about the lack of standards and need for quality control. One of the interviewees stated that:

"The Nigerian solar energy market is floated with products, but the quality and credibility of the technology cannot be trusted for both investors and end users".

2. Financial barriers: Economic status, initial capital and availability of incentive such as subsidies are factors that determine the adoption of solar energy initiatives in Nigeria. Two categories emerged as part of the analysis. They are financing of solar energy projects and low economic utilisation.

\section{a. Financing of solar energy projects}

Solar energy is free from sunlight; however, the deployment and development of the initiatives require financial commitment. The installation of solar PV facilities requires an initial capital for the PV panels and batteries which is cost intensive for low-income earners in Nigeria, especially the rural dwellers. There is a lack of access to financial sources, capital, credit, subsidised import duty, and high investment risk (Ozoegwu, et al. 2017). $88 \%$ ( 22 of the 25 ) interviewees asserted about the financing of solar energy projects. One of them noted that: 
“In 2013, 2014, the battery cost about N52,000/200/h, using 24 volts, in 2013 through 2014, solar panel was high, but the battery was cheap and in 2016 to 2017, the prices for solar panel reduced and the prices for battery is high. The current exchange rate is a challenge for the importers of solar panels and batteries'”.

\section{b. Low economic utilisation}

Private companies can now generate and distribute electricity from the energy mix of up to $100 \mathrm{~kW}$ mini grid and less than 1MW on medium scale (Nwokolo and Ogbulezie, 2018). Although, the rural dwellers are small scale farmers and herders, they are low-income earners, as a result, they cannot afford the deployment of solar energy initiative (Purohit and Purohit, 2017). Quansah (2016) argued that solar energy products in Nigeria lack true costing, valuation, skewed perverse incentives, and disclosures to any risk and effect to the end-user. 56\% (14 of the 25) interviewees perceived that there is a low economic utilisation. One of the interviewees stated that:

"Economics and earnings are one obstacle to the technology. The initial start-up is high and very few people can afford to buy and install this technology. You can relate the rural communities where businesses are slow and income earning is low to take care of basic needs".

3. Political Barriers: Three categories emerged as part of the analysis. They are lack policies and institutional barriers, political will and legislative issues, and legal and regulatory issues. 


\section{a. Policies and Institutional barriers}

Solar energy development in Nigeria is challenged with policies associated with lack of long-term planning and vision, lack of clarity of the power sector driving mission, lack of clarity in tariff bidding process and lack of bankable PPA for investors. Furthermore, the process of land acquisition for mini solar grid project is a barrier linked to the solar energy infrastructure (Aly, et al. 2019). Lack of strategic policies by the government seems not to encourage national and international investors and promoters for solar energy initiatives (Ohunakin, et al, 2014). 80\% (20 of the 25) interviewees noted the institutional laws and regulations can be a big obstacle to young entrepreneurs. Until the government policies are driving the economy the solar energy is yet to get the full potential for the implementation

\section{b. Lack of Political Will and Legislative issues}

Although Nigeria possesses renewable energy potentials, policies for good governance, political will and legislative framework to drive the potential element and translate them into reality is lacking (Jacobson and Jadhav, 2018). As a result, Nigeria is yet to have stable electricity for household and industrial use. $76 \%$ (19 of the 25) interviewees noted there is lack of political will and legislative issues. One of the interviewees stated that:

"Political will is a driver to achieving the objective of the energy mix, this driver is missing in Nigeria because of conflicting interest in the development and management of power sources, especially renewable energy like solar energy'”.

\section{c. Legal and regulatory issues}


Lack of policies and regulations for the development of solar energy can hinder the adoption of the initiative. There is also lack of adequate regulations for acquisition of land permits for solar farm siting, community relation procedure and negotiation with local communities. For solar energy initiative to thrive in Nigeria and other Sub-Sahara African countries, clear policies, procedures, and predictable mission for investors need to be stipulated. Furthermore, lack of supportive regulatory measures such as standard code of practice for the power sector could lead to risk of economic waste (Abdullahi, et al. 2017a). Solar energy development in Nigeria is challenged by legal, procedural, and environmental barriers, as a result the deployment and adoption of the initiative is slowed to meet the SDG goal 7 and vision 2020 and 2030 targets (Ozoegwu, et al. 2017). 72\% (18 of the 25) interviewees noted:

" Unless laws are adjusted to give solar energy promoters the opportunity to design, build and install solar energy, Nigeria will continue to experience power shortages'”.

4. Social Barriers: Two categories emerged as part of the analysis. They are sociocultural perception and low awareness.

\section{a. Socio-cultural perception}

Nigeria is a country with more than 350 ethnic groups where the Hausa, Igbo and Yoruba are the majority. There is a strong ethnic believes in cultures, tribal values, religion and gender which has an impact on how the initiative is perceived among tiers, as a result, the acceptance is low due to social believes (Aliyu, et al. 2015; Wadu Mesthrige and Kwong, 2018). The barriers have resulted in a financial loss for the distribution company of Nigeria, where the financial collections became almost impossible due to restriction of access to 
communities. Technical staff and supervisors from the power sector are likely to be denied access to many houses for surveys, assessment, inspection, and installation of electricity meters. The socio-cultural barriers affect the communities from generating socio-economic benefits of solar energy initiatives in the country. $92 \%$ (21 of the 25 ) interviewees of the respondent noted the solar energy usage cannot be fully accepted by end users due to the socio-cultural issues which makes it difficult to implement and use solar energy through Solar PVs: home system; water pumping; community service; refrigerator; street and traffic light; and farm plant/machinery.

\section{b. Low Awareness}

Developing solar energy initiatives in Nigeria is significantly affected by lack awareness campaign. This barrier is related to people's mindsets, principles, behaviour, perception, illiteracy and poor sensitisation about solar benefits to the end-user and promoters (Kar, et al., 2016).

People living in rural communities are mostly affected due to lack of grid connection and limited access to other energy options (Nwokocha, et al. 2018). Small-scale business suffers setback as a result the rate of unemployment is rising significantly, economic opportunities in local communities are disappearing and resources that contribute to the economic development remains unidentified (Emodi and Boo, 2015; Gandhi, 2020). 60\% (15 of the 25 ) interviewees stated that there is lack of awareness of the benefits of solar energy in the medium to long term.

\section{Findings and Discussion}


As revealed in this study, the successful implementation of solar energy initiatives is associated with barriers such as technological, financial, political and social aspects which has been the reason for slowing down solar energy development in Nigeria.

These barriers could change over time as the socio-economic aspects of Nigeria progresses in the implementation and usage of the solar energy. According to the response from the face-toface interview conducted, $100 \%$ of the interviewees noted that technical barrier is the major concern, because the promoters and end users lack the technical capacity on the knowhow of operation, installation, maintenance, and evaluation. Also, socio-cultural perceptions have also been a major barrier to deployment and implementation of solar energy initiatives. Although, literature argued that, communities where access to electricity is limited, have little knowledge and awareness about the benefit of solar energy initiative.

The Nigerian power sector has made attempts to generate, transmit and distribute sustainable electricity for over a century. It is, therefore, apparent for the government and private sector to propose and implement power recovery plan to meet the electricity demand in the country. The plan can integrate solar energy to generate electricity from solar PV to encourage the use of environmentally friendly energy sources.

The power sector needs to engage its stakeholder in dialogue to find the causes and solutions to the power outage in the country. The federal ministry of power together with its departments and agencies need to fast-tract the issues associated with the power failure and proffer lasting solutions.

Community leaders should be well informed about plan for solar energy development in order to create more awareness in communities. There needs to have a customer/end-users to have an interactive forum where the stakeholders communicate, consult, remind, plan, evaluate risk, and take responsibility for the success and failure of the solar energy sector. 
Solar PV is flexible and well suited for decentralised system in different sizes to contribute not only for energy poverty reduction but also for adoption into clean technology and climate change mitigation. There is a need to establish more energy research across the country in order to complement the five-energy research centres. The objectives for training and development for solar energy need to be strengthened to support the EPSRA objectives for energy mix.

There is a plan to integrate an independent power plant (IPPs) for the 37 Federal Universities and the 7 University teaching hospitals in Nigeria. The projects are expected to generate standalone solar off-grid system of capacity between 1MW to 10MW before the year 2030 (NACOP, 2016). Although, the implementation of IPPs for universities is slow, other tertiary institutions in the country should emulate the strategy in order to maximise electricity access.

It is evident that, there is a huge market for solar energy readily available for developers and promoters in Nigeria. However, the market is floated with substandard products for solar panels and accessories, as a result, consumers and promoters have little or no confidence in the initiative. Therefore, the standard organisation of Nigeria (SON) needs to take drastic measures to control goods and are produced locally and enforce strict standard specification on importation.

Government should provide options for credit facilities with low-interest rate through the micro finance bank and make it accessible to rural dwellers. The government should provide a scheme where low income earners can have an incentive for adopting solar energy option by subsidising solar energy equipment and waiving import duty to all solar energy promoters. The facilities will enable low income earners to adopt solar energy especially for small-scale industries which would boost socio-economic activities.

Power sector need to identify staff members to be trained to gain managerial, technical and organisational skills to manage solar energy policies, initiatives and its implementation. The 
stakeholders need to build an interface where young people can have access to technical skill training, improve knowledge about renewable energy and its benefits.

\section{Conclusion and Recommendation}

In this paper, potentials solar energy initiatives, status, opportunities, projects, policies, progress and retrogression have been identified, efforts made for scaling up solar projects has been measured with areas of improvement. Barriers deterring the progress for deployment and development of solar energy initiatives were identified and discussed from literature and interviewee's points of view. Lack of technical knowledge, socio-cultural issues and lack of suitable financing mechanism were among the key solar energy barriers. In order to mitigate the barriers and develop solar energy initiatives in Nigeria, enforceable and sustainable policies have become necessary. The data for this paper was collected qualitatively from 25 participants who are well experienced top level management staff in the Nigerian power sector and renewable energy development and data was analysed by content analysis.

The implication of this research is to impact the organisations within the Nigerian power sector that are intending to implement solar energy initiatives. Identifying solar energy barriers would help top management to make positive decisions to plan and adapt more appropriate initiatives while considering technological, financial, political and social perceptions to ensure successful implementations.

It is recommended to encourage community participation, especially young people in the promotion and ownership of solar energy initiatives throughout the country. The PPP should integrate financial subsidy incentive to individuals and private organisation's willing to invest in the promotion, deployment, and development of solar energy initiatives. Promotion of the solar energy initiative is challenged by lack of awareness and the socio-economic benefits. 
Academic institutions should integrate solar energy technical and management courses to support the spread awareness for the promotion of solar energy. Therefore, the Ministries, Departments and Agencies (MDAs) need to make more efforts to raise awareness through the integration of solar energy into schools, colleges, and universities curriculum. This study will provide an advantage to organisations that are in the process of implementing solar energy initiatives. Moreover, this research will also assist policymakers regarding the formulation of policies on solar energy products. An undue advantage of this would be the increasing adoption of solar energy by understanding the barriers that impact the implementation not only in Nigeria but in other developing countries.

\section{References}

Abdullahi, D., Suresh, S., Renukappa, S. and Oloke, D. (2017), "Key Barriers to the Implementation of Solar Energy in Nigeria: A Critical Analysis", IOP Conference Series: Earth and Environmental Science, vol. 83, pp. 12015.

Abubakar Mas'ud, A., Wirba, A.V., Muhammad-Sukki, F., Albarracín, R., Abu-Bakar, S.H., Munir, A.B. \& Bani, N.A. (2016), "A review on the recent progress made on solar photovoltaic in selected countries of sub-Saharan Africa", Renewable and Sustainable Energy Reviews, vol. 62, pp. 441-452, doi:10.1016/j.rser.2016.04.055.

Adelaja, A.O. (2020), "Barriers to national renewable energy policy adoption: Insights from a case study of Nigeria", Energy strategy reviews, vol. 30, pp. 100519, doi:10.1016/j.esr.2020.100519.

Adesanya, A., Misra, S., Maskeliunas, R. and Damasevicius, R. (2020), "Prospects of oceanbased renewable energy for West Africa's sustainable energy future", Smart and 
Sustainable Built Environment, Vol. ahead-of-print No. ahead-ofprint. https://doi.org/10.1108/SASBE-05-2019-0066

Ajayi, O., Fagbenle, R., Katende, J., Ndambuki, J., Omole, D. \& Badejo, A. (2014), "Wind Energy Study and Energy Cost of Wind Electricity Generation in Nigeria: Past and Recent Results and a Case Study for South West Nigeria", Energies, vol. 7, no. 12, pp. 8508-8534, doi: $10.3390 /$ en7128508.

Akinyele, D., Babatunde, O., Monyei, C., Olatomiwa, L., Okediji, A., Ighravwe, D., Abiodun, O., Onasanya, M. \& Temikotan, K. (2019), "Possibility of solar thermal power generation technologies in Nigeria: Challenges and policy directions", Renewable Energy Focus, vol. 29, pp. 24-41, doi:10.1016/j.ref.2019.02.002.

Akinyele, D.O., Rayudu, R.K. \& Nair, N.K.C. (2015), "Global progress in photovoltaic technologies and the scenario of development of solar panel plant and module performance estimation - Application in Nigeria", Renewable and Sustainable Energy Reviews, vol. 48, pp. 112-139, doi: 10.1016/j.rser.2015.03.021.

Akuru, U.B., Onukwube, I.E., Okoro, O.I. \& Obe, E.S. (2017), "Towards 100\% renewable energy in Nigeria", Renewable and Sustainable Energy Reviews, vol. 71, pp. 943-953, doi: $10.1016 /$ j.rser.2016.12.123.

Aliyu, A.S., Dada, J.O. \& Adam, I.K. (2015), "Current status and future prospects of renewable energy in Nigeria", Renewable and Sustainable Energy Reviews, vol. 48, pp. 336-346, doi: 10.1016/j.rser.2015.03.098.

Aly, A., Moner-Girona, M., Szabó, S., Pedersen, A.B. \& Jensen, S.S. (2019), "Barriers to Large-scale Solar Power in Tanzania", Energy for Sustainable Development, vol. 48, pp. 43-58, doi: $\underline{10.1016 / \text { j.esd.2018.10.009. }}$. 
Creswell, J. W and Creswell, J. D., (2018), Research design: qualitative, quantitative, and mixed method Approaches, Los Angeles: Sage. ISBN: 9781506386768.

Dada, J.O. (2014), "Towards understanding the benefits and challenges of Smart/Micro-Grid for electricity supply system in Nigeria", Renewable and Sustainable Energy Reviews, vol. 38, pp. 1003-1014, doi: 10.1016/j.rser.2014.07.077.

Dinçer, F. (2011), "The analysis on photovoltaic electricity generation status, potential and policies of the leading countries in solar energy", Renewable and Sustainable Energy Reviews, vol. 15, no. 1, pp. 713-720, doi: 10.1016/j.rser.2010.09.026.

Emodi, N.V. \& Boo, K. (2015), "Sustainable energy development in Nigeria: Current status and policy options", Renewable and Sustainable Energy Reviews, vol. 51, pp. 356-381. Doi: 10.1016/j.rser.2015.06.016.

Fagbenle, R.O., Katende, J., Ajayi, O.O. \& Okeniyi, J.O. (2011), "Assessment of wind energy potential of two sites in North-East, Nigeria", Renewable Energy, vol. 36, no. 4, pp. 1277-1283, doi: 10.1016/j.renene.2010.10.003.

Gandhi, A.V. (2020), "Studying green consumer behavior through multiple lenses in a developing country", Smart and Sustainable Built Environment, Vol. ahead-of-print No. ahead-of-print. https://doi.org/10.1108/SASBE-01-2019-0011

Giwa, A., Alabi, A., Yusuf, A. \& Olukan, T. (2017), "A comprehensive review on biomass and solar energy for sustainable energy generation in Nigeria", Renewable and Sustainable Energy Reviews, vol. 69, pp. 620-641, doi: 10.1016/j.rser.2016.11.160.

Haas, J., Palma-Behnke, R., Valencia, F., Araya, P., Díaz-Ferrán, G., Telsnig, T., Eltrop, L., Díaz, M., Püschel, S., Grandel, M., Román, R. \& Jiménez-Estévez, G. (2018), "Sunset or sunrise? Understanding the barriers and options for the massive deployment of solar 
technologies in Chile", Energy Policy, vol. 112, pp. 399-414, doi: $\underline{\text { 10.1016/j.enpol.2017.10.001. }}$

Jacobson, M.Z. \& Jadhav, V. (2018), "World estimates of PV optimal tilt angles and ratios of sunlight incident upon tilted and tracked PV panels relative to horizontal panels", Solar Energy, vol. 169, pp. 55-66, doi: 10.1016/j.solener.2018.04.030.

K, N.O. \& N, D.V. (2016), "Objective criteria ranking framework for renewable energy policy decisions in Nigeria", IOP Conference Series: Earth and Environmental Science, vol. 40, pp. 12055. Available at: http://tinyurl.com/y5epjacr.

Kar, S.K., Sharma, A. and Roy, B. (2016), "Solar energy market developments in India", Renewable and Sustainable Energy Reviews, vol. 62, pp. 121-133, doi: $\underline{10.1016 / j . r s e r .2016 .04 .043}$.

Kumar, V., Syan, A.S. and Kaur, K. (2020), "A structural equation modeling analysis of factors driving customer purchase intention towards solar water heater", Smart and Sustainable Built Environment, Vol. ahead-of-print No. ahead-of-print. https://doi.org/10.1108/SASBE-05-2020-0069

Labordena, M., Patt, A., Bazilian, M., Howells, M., Lilliestam, J., Skolan för industriell teknik och management (ITM), KTH, Energiteknik \& Energisystemanalys (2017), "Impact of political and economical barriers for concentrating solar power in Sub-Saharan Africa", Energy Policy, vol. 102, pp. 52, doi: 10.1016/j.enpol.2016.12.008.

Manju, S. \& Sagar, N. (2017), "Progressing towards the development of sustainable energy: A critical review on the current status, applications, developmental barriers and prospects of solar photovoltaic systems in India", Renewable and Sustainable Energy Reviews, vol. 70, pp. 298-313, doi: 10.1016/j.rser.2016.11.226.

Mohammed, Y.S., Mustafa, M.W., Bashir, N. \& Ibrahem, I.S. (2017), "Existing and recommended renewable and sustainable energy development in Nigeria based on 
autonomous energy and microgrid technologies", Renewable and Sustainable Energy Reviews, vol. 75, pp, doi: 10.1016/j.rser.2016.11.062.

Monyei, C.G., Adewumi, A.O., Obolo, M.O. \& Sajou, B. (2018), "Nigeria's energy poverty: Insights and implications for smart policies and framework towards a smart Nigeria electricity network", Renewable and Sustainable Energy Reviews, vol. 81, pp. 15821601, doi: 10.1016/j.rser.2017.05.237.

NACOP, (2016), Sustainable Energy for All Action Agenda (SE4ALL-AA) Available at:http://power.gov.ng/Press\%20Release/SUSTAINABLE\%20ENERGY\%20FOR\%20 ALL\%20ACTION\%20AGENDA\%20(SEE4ALL-AA).pdf. [Accessed 29 January 2020].

NERC, (2015), Renewable Energy Sourced Electricity. Available at:http://www.nercng.org/index.php/home/operators/renewable-energy. [Accessed 18 January 2020].

JICA, (2016) Nigeria Receives Grant from Japan International Cooperation for Solar PV Project in Nigeria 2016, Global Data Ltd, London. Available at:https://www.esiafrica.com/industry-sectors/renewable-energy/japans-jica-funds-solar-powernigeria/.[Accessed 31August 2020].

Ndanusa Babakatcha, Jibrin Alhaji Yabagi, Muhammad Bello Ladan and Muyodeen Dawodu Oladipupo (2020), "Harnessing solar energy potential as an alternative source of electrical energy in north central, Nigeria”, African Journal of Environment and Natural Science Research, Volume 3, Issue 4, ISSN: 2689-9434, pp. 86-94.

Nova/KSG - Katsina Solar Power Plant 125 MW - Nigeria - Project Profile (2018), Progressive Media Group, London. Available at:https://www3.opic.gov/Environment/EIA/novasolar/ESIA_Main_Chapters.pdf. [Accessed 29 August 2020]. 
Nwokocha, C.O., Okoro, U.K. \& Usoh, C.I. (2018), "Photovoltaics in Nigeria - Awareness, attitude and expected benefit based on a qualitative survey across regions", Renewable Energy, vol. 116, pp. 176-182, doi: 10.1016/j.renene.2017.09.070.

Nwokolo, S.C. \& Ogbulezie, J.C. (2018), "A qualitative review of empirical models for estimating diffuse solar radiation from experimental data in Africa", Renewable and Sustainable Energy Reviews, vol. 92, pp. 353-393, doi: 10.1016/j.rser.2018.04.118.

Ogunmodimu, O. \& Okoroigwe, E.C. (2018), "Concentrating solar power technologies for solar thermal grid electricity in Nigeria: A review", Renewable and Sustainable Energy Reviews, vol. 90, pp. 104-119, doi: 10.1016/j.rser.2018.03.029.

Ohunakin, O.S., Adaramola, M.S., Oyewola, O.M. \& Fagbenle, R.O. (2014), "Solar energy applications and development in Nigeria: Drivers and barriers", Renewable and Sustainable Energy Reviews, vol. 32, pp. 294-301, doi: 10.1016/j.rser.2014.01.014.

Okeowo, M. (2018), "How an increase in power supply has ensured less spending on alternative power for Nigerian manufacturers", Ventures Africa: https://search-proquestcom.proxy.library.dmu.ac.uk/docview/2157938053?accountid=10472. [Accessed 22 January 2020].

Oseni, M.O. (2012), "Improving households' access to electricity and energy consumption pattern in Nigeria: Renewable energy alternative", Renewable and Sustainable Energy Reviews, vol. 16, no. 6, pp. 3967-3974, doi: 10.1016/j.rser.2012.03.010.

Osinowo, A.A., Okogbue, E.C., Ogungbenro, S.B. \& Fashanu, O. (2015), "Analysis of Global Solar Irradiance over Climatic Zones in Nigeria for Solar Energy Applications", Journal of solar energy, vol. 2015, pp. 1-9. Available at: http://tinyurl.com/yygmek25. [Accessed 31 August 2020]. 
Oyedepo, S.O. (2014), "Towards achieving energy for sustainable development in Nigeria", Renewable and Sustainable Energy Reviews, vol. 34, pp. 255-272, doi: 10.1016/j.rser.2014.03.019.

Ozoegwu, C.G. (2018), "The solar energy assessment methods for Nigeria: The current status, the future directions and a neural time series method", Renewable and Sustainable Energy Reviews, vol. 92, pp. 146-159, doi: 10.1016/j.rser.2018.04.050.

Ozoegwu, C.G., Mgbemene, C.A. \& Ozor, P.A. (2017), "The status of solar energy integration and policy in Nigeria", Renewable and Sustainable Energy Reviews, vol. 70, pp. 457471, doi: $\underline{10.1016 / \text { j.rser.2016.11.224. }}$.

Pillot, B., Muselli, M., Poggi, P. \& Dias, J.B. (2019), "Historical trends in global energy policy and renewable power system issues in Sub-Saharan Africa: The case of solar PV", Energy Policy, vol. 127, pp. 113-124, doi: 10.1016/j.enpol.2018.11.049.

Purohit, P. \& Purohit, I. (2017), "Technical and economic potential of concentrating solar thermal power generation in India", Renewable and Sustainable Energy Reviews, vol. 78, pp. 648-667, doi: 10.1016/j.rser.2017.04.059.

Quansah, D.A., Adaramola, M.S. \& Mensah, L.D. (2016), "Solar Photovoltaics in Sub-Saharan Africa - Addressing Barriers, Unlocking Potential", Energy Procedia, vol. 106, pp. 97110, doi: $10.1016 /$ j.egypro.2016.12.108.

Ramli, M.A.M., Prasetyono, E., Wicaksana, R.W., Windarko, N.A., Sedraoui, K. \& Al-Turki, Y.A. (2016), "On the investigation of photovoltaic output power reduction due to dust accumulation and weather conditions", Renewable Energy, vol. 99, pp. 836-844, doi: $\underline{10.1016 / j . r e n e n e .2016 .07 .063 . ~}$

REA, (2018). Nigeria is the biggest and most attractive off-grid opportunity in Africa, and one of the best locations in the world for mini-grids. Available at:http://rea.gov.ng/minigrids/. [Accessed 25 August 2020]. 
Scatec Solar acquires 100MW Nova Scotia solar project in Nigeria (2016), Global Data Ltd, London.

Shukla, A.K., Sudhakar, K., Baredar, P. \& Mamat, R. (2018), "Solar PV and BIPV system: Barrier, challenges and policy recommendation in India", Renewable and Sustainable Energy Reviews, vol. 82, pp. 3314-3322, doi: 10.1016/j.rser.2017.10.013.

The biggest solar projects in Africa. Available at: https://www.powertechnology.com/features/the-biggest-solar-projects-in-africa/. [Accessed 28 December 2019].

Timilsina, G.R., Kurdgelashvili, L. \& Narbel, P.A. (2012), "Solar energy: Markets, economics and policies", Renewable and Sustainable Energy Reviews, vol. 16, no. 1, pp. 449-465, doi: 10.1016/j.rser.2011.08.009.

Ugulu, A.I. \& Aigbayboa, C. (2019), "Motives for solar photovoltaic (PV) adoption in urban Nigeria", IOP conference series. Earth and environmental science, vol. 385, pp. 12012, doi: $10.1088 / 1755-1315 / 385 / 1 / 012012$.

Wadu Mesthrige, J. and Kwong, H.Y. (2018), "Criteria and barriers for the application of green building features in Hong Kong", Smart and Sustainable Built Environment, Vol. 7 No. 3/4, pp. 251-276. https://doi.org/10.1108/SASBE-02-2018-0004

Wyllie, J.O.Y., Essah, E.A. \& Ofetotse, E.L. (2018), "Barriers of solar energy uptake and the potential for mitigation solutions in Barbados", Renewable and Sustainable Energy Reviews, vol. 91, pp. 935-949, doi: 10.1016/j.rser.2018.04.100.

Zhang, X., Shen, L. \& Chan, S.Y. (2012), "The diffusion of solar energy use in HK: What are the barriers?", Energy Policy, vol. 41, no. 1, pp. 241-249, doi: 10.1016/j.enpol.2011.10.043. 
Zou, Y.W., Ji, W.H. \& Sang, Y.J. (2014), "Status and trends of renewable energy harvesting", Trans Tech Publications Ltd, Zurich, pp. 422, doi: 10.4028/www.scientific.net/AMM.672-674.422. 


\section{Figures}

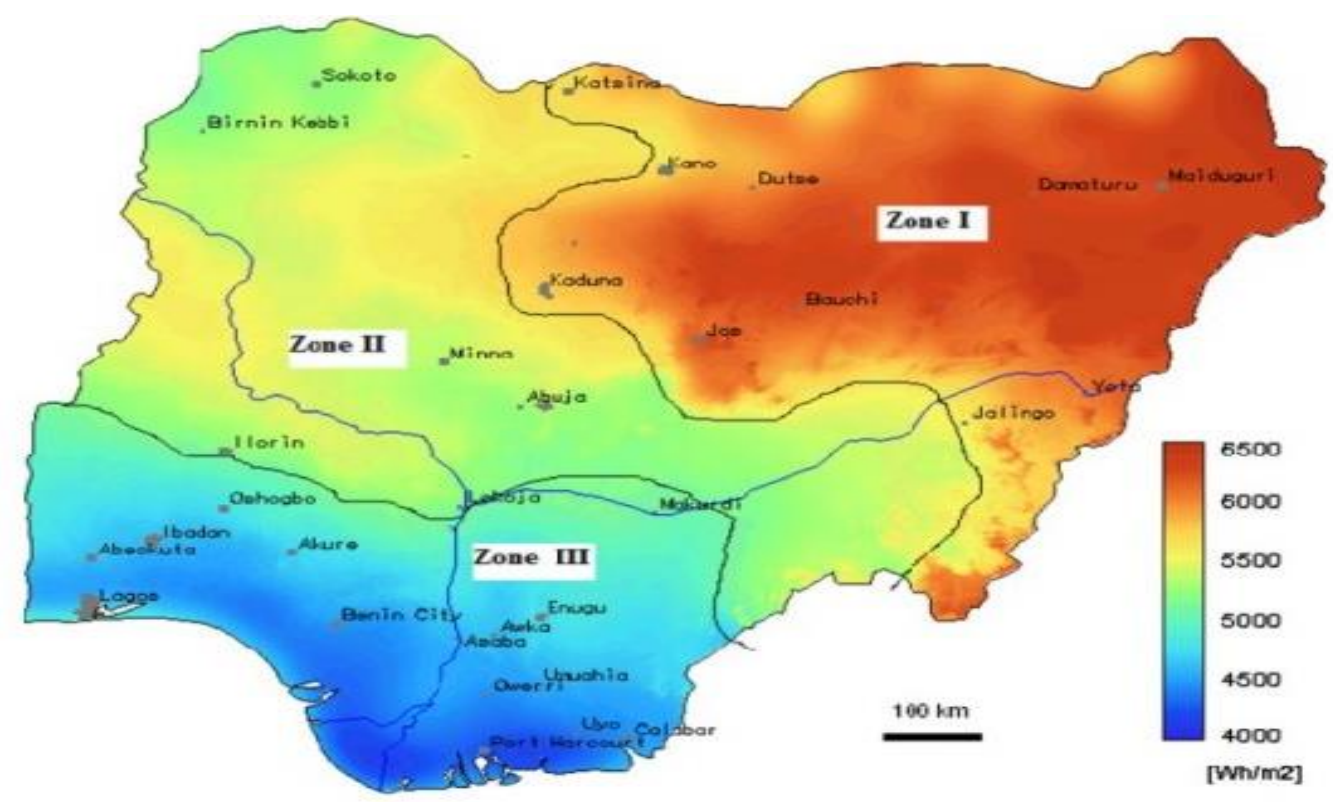

Source: Aliyu, et al. 2015

Figure 1: Sun irradiation level in Nigeria 
Table 1: Solar energy use in Nigeria

\begin{tabular}{|l|l|l|l|l|}
\hline No & Activities & \multicolumn{2}{l|}{ Timeline and Quantity } \\
\cline { 3 - 5 } & & $\begin{array}{l}\text { Short-term } \\
(\mathbf{M W}) \\
\mathbf{2 0 0 6}-\mathbf{2 0 0 9}\end{array}$ & $\begin{array}{l}\text { Medium-term } \\
(\mathbf{M W}) \\
\mathbf{2 0 1 0}-\mathbf{2 0 1 5}\end{array}$ & $\begin{array}{l}\text { Long-term } \\
\text { (MW) } \\
\mathbf{2 0 1 6}-\mathbf{2 0 3 0}\end{array}$ \\
\hline 1 & Solar PV home system & 5 & 10 & 15 \\
\hline 2 & Solar PV water pumping & 50 & 1000 & 5000 \\
\hline 3 & Solar PV community service & 45 & 500 & 3000 \\
\hline 4 & Solar PV refrigerator & 20 & 500 & 2000 \\
\hline 5 & Solar PV street and traffic light & 100 & 1000 & 10000 \\
\hline 6 & Solar PV (farm plant) & 80 & 990 & 18,127 \\
\hline 7 & Solar thermal electricity & 300 & 2136 & 48,132 \\
\hline & Total (MW) & 600 & 6136 & \\
\hline
\end{tabular}

Source: (Mas'ud, et al. 2017).

Table 2: Major Solar projects in Nigeria

\begin{tabular}{|c|c|c|c|c|c|}
\hline $\mathbf{S} / \mathbf{N}$ & Name of Solar projects & $\begin{array}{c}\text { Capacity } \\
\text { (MW) }\end{array}$ & Type & Location & Proponent \\
\hline 1 & Anjeed Kafanchan Solar Ltd & 50 & Solar & Kaduna & Anjeed Innoval Ltd \\
\hline 2 & PV Grid - tied generator system & 50 & Solar & Osun & Book Solar Investment \\
\hline 3 & Ever Power Solar power plant & 50 & Solar & Kaduna & Quaint Global Energy \\
\hline 4 & Solar Farm Projects & 200 & Solar & Borno & Borno State Govt. \\
\hline 5 & Solar Farm at Kado & 59 & Solar & Kaduna & Synergent powershire \\
\hline 6 & Solar Indep. Power Project & 100 & Solar & Bauchi & Nigerian Solar Capital \\
\hline 7 & Solar PV Power Projects & 50 & Solar & Sokoto & Geo Envi. services \\
\hline 8 & Solar Farm Projects & 30 & Solar & Katsina & Katsina State Govt. \\
\hline 9 & Japanese Grand Solar Power & 0.9 & Solar & FCT & Fed.Min. of Power \\
\hline 10 & On-Grid Solar Power & 200 & Solar & FCT & 99 Effect Energy Ltd \\
\hline 11 & PV-Solar Farm Kankia & 20 & Solar & Katsina & Katsina State Govt. \\
\hline 12 & Solar Project Danmarke & 75 & Solar & Zamfara & SPGS Power Ltd \\
\hline 13 & Solar Power Plant Panyam & 50 & Solar & Plateau & CT Cosmos Ltd \\
\hline 14 & Solar Farm Riko, Jibiya & 10 & Solar & Katsina & Sinosum Investment \\
\hline 15 & Solar Gen. Plant Damaturu & 1000 & Solar & Yobe & GOPA Int.Energy Cslt \\
\hline 16 & PV Power Plant FCT Area & 100 & Solar & FCT & LR-Aaron Power Ltd \\
\hline 17 & Shiroro Solar Power Projects & 300 & Solar & Niger & N/South Power Co. Ltd \\
\hline 18 & Solar Power Plant Irewole & 50 & Solar & Osun & Remix Energy Ltd \\
\hline 19 & Solar Power Plant, Bakura & 150 & Solar & Zamfara & PV Bakura \\
\hline 20 & Solar Power Plan Owo & 25 & Solar & Ondo & Secusafe Limited \\
\hline 21 & Solar Farm Gusau & 50 & Solar & Zamfara & Sinosun Investment \\
\hline 22 & Solar Farm Kiru & 40 & Solar & Kano & Bravos Energy Res. \\
\hline
\end{tabular}




\begin{tabular}{|l|l|c|l|l|l|}
\hline 23 & Solar Project Kankia & 125 & Solar & Katsina & Nova Solar 5 Farms \\
\hline 24 & Solar Energy Projects Udi & 1200 & Solar & Enugu & Motir Seapire Energy \\
\hline 25 & Solar Power Plant, Ilorin South & 150 & Solar & Kwara & Oroceram Limited \\
\hline 26 & Solar Power Plant, Paiko LGA & 150 & Solar & Niger & Oroceram Limited \\
\hline 27 & Solar Power Plant, Dutse & 75 & Solar & Jigawa & PAS Dutse Ltd \\
\hline 38 & Solar Power Plant Hadejia & 75 & Solar & Jigawa & PAS Dutse Ltd \\
\hline 39 & Solar Power Projects Gwa AC & 100 & Solar & FCT & Enerlog Limited \\
\hline 30 & Solar Projects, Yabo & 100 & Solar & Sokoto & KVK Power \\
\hline 31 & Solar Power Plant, Kankia & 80 & Solar & Katsina & Pan African Solar Ltd \\
\hline 32 & Solar Power Plant, Bakura & 300 & Solar & Zamfara & Bakura Energy Ltd \\
\hline 33 & Solar Plant Kokona & 50 & Solar & Nasarawa & Afringia Power Ltd \\
\hline 34 & Solar Power Plant, Numan & 35 & Solar & Adamawa & Hill Crest Env. Mgt \\
& & & & & Ltd \\
\hline 35 & Renewable Energy Owo & 10 & Solar & Ondo & Gottpower Limited \\
\hline
\end{tabular}

Source: (Ohunakin, et al. 2014); (NACOP, 2016).

Table 3: Key Institutions Responsible for Electricity deployment in Nigeria

\begin{tabular}{|l|l|}
\hline $\mathbf{S} / \mathbf{N}$ & Institutions \\
\hline 1 & Federal ministry of power \\
\hline 2 & Nigerian Electricity Regulatory Commission \\
\hline 3 & Energy Commission of Nigeria \\
\hline 4 & Rural Electrification Agency \\
\hline 5 & Niger Delta Power Holding Company Limited \\
\hline 6 & Nigeria Bulk Electricity Trading \\
\hline 7 & Operator of the Nigerian Electricity Market \\
\hline 8 & National Power training Institute of Nigeria \\
\hline 9 & National Electricity Liability Management Company Limited \\
\hline 10 & \\
\hline
\end{tabular}

Source: (NERC, 2020)

Table 4: Research Participants 


\begin{tabular}{|l|l|l|l|}
\hline S/N & Participants & Number of Interviewees & Years of Experience \\
\hline 1 & Executive Directors & 3 & $4-23$ Years \\
\hline 2 & Directors & 6 & $15-21$ Years \\
\hline 3 & Deputy Directors & 3 & $12-16$ Years \\
\hline 4 & National Coordinators & 5 & $12-19$ Years \\
\hline 5 & Managers & 5 & $14-19$ Years \\
\hline 6 & Head of Departments (Renewable) & 1 & 11 Years \\
\hline 7 & Deputy Governor (C. Bank) & 1 & 22 Years \\
\hline 8 & Chairperson (RE Projects) & 1 & 20 Years \\
\hline
\end{tabular}

